\title{
EDITORIAL
}

\section{¿Fin de mundo?}

"La muerte propia no se puede concebir; tan pronto intentamos hacerlo podemos notar que en verdad sobrevivimos como observadores. (...) En el fondo, nadie cree en su propia muerte, o, lo que viene a ser lo mismo, en el inconsciente cada uno de nosotros está convencido de su inmortalidad".

S. Freud. De guerra y muerte. Temas de actualidad (1915)

En sus inicios este número de Etica y Cine Journal fue concebido para plasmar una selección de los trabajos presentados en la segunda bienal de Cine y Psicoanálisis realizada en Aix-en-Provence, Francia, en Abril de 2019. Entre aquel evento y esta edición medió casi un año, signado durante los últimos meses por la expansión a escala global del corononavirus. Una realidad que entró rápidamente en la vida diaria de nuestros países, nuestras ciudades, nuestras universidades, nuestros consultorios, nuestras familias. De manera imprevista, como el fantasma devastador que tan bien describió Albert Camus en La peste: "La gran ciudad silenciosa no fue entonces más que un conjunto de cubos macizos inertes, entre los cuales las efigies taciturnas de bienhechores olvidados o de antiguos grandes hombres, ahogados para siempre en el bronce, intentaban únicamente, con sus falsos rostros de piedra o hierro, invocar una imagen desvaída de lo que había sido el hombre."

Esta dura realidad nos permitió volver sobre el material con nuevos ojos y sorprendernos ante el valor de anticipación que tenían varios de los textos, lo que reafirmó el valor de su publicación. Es que también el cine, como la literatura de Camus, se anticipó a este paisaje inquietante en el que se va convirtiendo el planeta. El comentario inicial de Michele Benhahim y Vladimir Broda sobre los filmes Melancolía y Solo el fin del mundo con que abrimos el número, es un claro ejemplo de ello. Dos catástrofes, el impacto de un meteorito gigante y la pandemia del Sida, ponen en evidencia la doble vulnerabilidad de la condición humana tan bien descripta por Freud. ${ }^{1}$

Ambas dimensiones aparecen en este paralelo de Benhaim y Broda: pondremos en tensión los procesos narrativos y fílmicos usados en Melancolía y en Solo el fin del mundo para representar y expresar una reflexión filosófica sobre lo irrepresentable y lo indecible de la desaparición inminente y anunciada de uno mismo: ya sea como individuo o para todo el planeta, siendo ambas vivencias de "fin del mundo". ${ }^{2}$

En esta misma línea, hemos decidido cerrar el número con el artículo compartido con Eduardo Laso que presenta el valor del cine en este contexto ominoso: el cine como pasador de lo real. ¿Cuál es la función del cine frente a la catástrofe? Leemos allí: "Elaborar un trauma -individual o colectivo- supone el trabajo arduo de simbolizar un exceso situacional que ha arrasado al sujeto y a la Polis, con el objeto de hacer pasar ese real al campo de lo representable." Y si el el siglo XX podría pensarse como una época pletórica en eventos desastrosos, el panorama actual no es mucho más alentador. Frente a estas catástrofes de la humanidad, ¿cómo simbolizar lo real traumático, cuando éste se presenta bajo la forma del goce mortificante del semejante? ¿Como hacer que una epidemia no transforme al hombre en lobo del hombre?

Tanto el psicoanálisis como el arte emprenden, por vías distintas, esta ardua tarea de hacer pasar lo real a lo simbólico, de inscribir lo imposible. De dar imágenes, palabras y representaciones a aquello que en principio está ausente, silenciado, rechazado, a la espera de ser reconocido, para que deje de ser una herida abierta, instalada como repetición vana.

En ese marco se despliega la galería de trabajos que integra el número. Desde el escrito "La mirada a través de la cámara: Cine, escenas puberales y teorías sexuales juveniles", de Christian Bonnet, Clarisse Vollon, Guy Gimenez y Julie Chevalier; o "La batalla de Chile: imagen, poesía, memoria”, sobre el portentoso film chileno "Nostalgia de la luz", de Patricio Guzmán, por Derek Humphreys; el real del Holocausto, leido en el film de Pasolini Saló o los 120 días de Sodoma, a través del escrito "Poner en crisis a la política, la ética y la estética", de Isée Bernateau. Y cierran la serie la "Trilogía de Dolan: 
¿dos o tres?”, de Nicolas Rabain, y el trabajo de Delphine Scotto Di Vettimo, con un nuevo giro de su investigación sobre "Frida Kahlo: la mirada del cine".

Y por cierto una primicia en nuestra reseña de libros: el recién editado "Imaginarios de los trastornos mentales en las series", de Jorge Martínez Lucena e Irene Cambra Badii, con comentario de Paula Mastandrea y Lucía Amatriain.

Como suplemento extraordinario, un inédito en español de Jean-Claude Milner que aborda otra tragedia contemporánea, opacada a medias por el coronavirus: el abuso sobre los cuerpos femeninos. Con la aparición de este número, el 11 de marzo de 2020, el productor cinematográfico estadounidense Harvey Weinstein fue sentenciado a 23 años de prisión por acoso, abuso sexual e incluso violaciones. Recordemos que Weinstein se había hecho famoso en la década del 80 cuando junto a su hermano Bob fundaron la legendaria compañía Miramax, artífice de grandes éxitos, como Shakespeare in Love (1998), Pulp Fiction (1994), El paciente inglés (1996) y El discurso del rey (2010) entre muchas otros. ¿Cómo pudo una persona de tal sensibilidad artística incurrir en semejante degradación y vejación? La revelación de las escandalosas inconductas sexuales de Wainstein abrió un debate sobre el séptimo arte, la lógica del mercado y el tratamiento de los cuerpos en el capitalismo. El artículo de Jean-Claude Milner, constituye seguramente la reflexión filosófico-analítica más profunda sobre el tema. Etica y Cine Journal lo publica con la cuidada traducción y notas de Valentín Huarte, como un imprescindi- ble aporte a una discusión que debe permanecer abierta bajo cualquier circunstancia.

Porque como bien lo señaló Slavoj Žižek, la actual expansión de la epidemia de coronavirus ha detonado las epidemias de virus ideológicos que estaban latentes en nuestras sociedades: desde hipocresías y teorías conspirativas paranoicas hasta explosiones de racismo. La lectura del film El invasor, cuyo traveling inicial fue proyectado en la Bienal junto a un pasaje de L'Humanité, de Bruno Dumont, sintetizan en un fotograma este otro real cuya sombra enluta a Europa.

Pero las tragedias son también la oportunidad de una invención. La puesta a prueba de nuestra capacidad de creación ante un lazo social que debe ser reanudado. En palabras de Fernando Sabino, "Hacer de la interrupción un camino nuevo, hacer de la caída un paso de danza, del miedo una escalera, del sueño un puente, de la búsqueda un encuentro". ${ }^{3}$

Michèle Benhaim

Delphine Scotto

Christian Bonnet

Irene Cambra Badii

Mariana Gómez

Noelia Luzar

Eduardo Laso

Juan Jorge Michel Fariña

Aix-en-Provence, Barcelona, Buenos Aires, Córdoba, marzo 2020

\footnotetext{
$1 \quad$ El pasaje completo de Freud sobre la doble vulnerabilidad de la condición humana: “Ahí están los elementos, que parecen burlarse de todo yugo humano: la Tierra, que tiembla y desgarra, abismando a todo lo humano y a toda obra del hombre; el agua, que embravecida lo anega y lo ahoga todo; el tifón, que barre cuanto halla a su paso; las enfermedades, que no hace mucho hemos discernido como los ataques de otros seres vivos; por último, el doloroso enigma de la muerte, para la cual hasta ahora no se ha hallado ningún bálsamo ni es probable que se lo descubra." (Sigmund Freud, 1927, El porvenir de una ilusión)
}

2 Nous mettrons en tension des procédés de narration et des procédés filmiques utilisés dans Melancholia et dans Juste La Fin Du Monde pour représenter et exprimer une réflexion philosophique sur un point d'irreprésentable ou d'indicible relatif à la disparition proche et annoncée de soi-même : soi seul ou la planète comme vécus similaires de «fin du monde » (Benhaim y Broda, en el presente número de Ética y Cine Journal)

3 El poema completo de Sabino "De todo quedaron tres cosas" fue incluido en "Geopolítica del espanto y (po)ética de la reconstrucción”, prólogo a Lo Disruptivo, de Moty Benyakar (2006):

De todo quedaron tres cosas:

la certeza de que estaba siempre comenzando,

la certeza de que había que seguir

y la certeza de que sería interrumpido antes de terminar.

Hacer de la interrupción un camino nuevo,

hacer de la caída, un paso de danza,

del miedo, una escalera,

del sueño, un puente,

de la búsqueda,...un encuentro. 